\title{
Tilapia Oreochromis niloticus - A Choice of Aqua Farming \\ Mauro Lenzi
}

Lagoon Ecology and Aquaculture Laboratory (LEALab), Orbetello Pesca Lagunare Company, Italy

*Corresponding author: Mauro Lenzi, Lagoon Ecology and Aquaculture Laboratory (LEALab), Orbetello Pesca Lagunare Company, Italy, Tel: +39 3487 304274; Fax: +390564 867572; E-mail: lealab1@gmail.com

Rec date: July 21, 2016; Acc date: July 22, 2016; Pub date: July 25, 2016

Copyright: (C) 2016 Lenzi M. This is an open-access article distributed under the terms of the Creative Commons Attribution License, which permits unrestricted use, distribution, and reproduction in any medium, provided the original author and source are credited.

\section{Editor's note}

Aquaculture or aqua farming is growing rapidly as an industry in the modern era, as people are health conscious these days and are further specific about what they consume. Aquaculture involves cultivating freshwater and saltwater populations under controlled conditions. According to FAO, it is the farming of fish, crustaceans, molluscs and aquatic plants. Aquaculture started as early as $6000 \mathrm{BC}$ in Egypt and it is prevalent in Roman and German civilizations also.

The Nile tilapia species is native of Egypt, Israel and Africa and it is further spread to countries like Brazil. Nile fish is reputedly known as mango fish, though it is called as trash fish because of its black colored flesh. This variety is growing widely.

\section{Seagrass Community in the Kei Besar District, Maluku Regency}

Researcher Beruat A, et al. meticulously investigated and reported about the four seagrass communities in the study region and the study significantly contributed to the aquatic ecosystem. Some fish species feed on seagrasses and also supports reproduction. It is helpful in trapping sediments by slowing down the water movement, in turn trapping of sediment benefits of corals. This study concludes in line with the report of Decree of the Ministry of Environment No. 200 of 2004.

\section{Increasing Growth of Nile Tilapia and its Antioxidant Activity by Dietary Fructooligosaccharide}

An interesting study was conducted by scientist El-Gawad EAA, et al. to investigate the effects on the antioxidant activity, non-specific immunity and growth performance of Nile tilapia by feeding Dietary Fructooligosaccharide. Results were reported to be Serum immunoglobulin M, Nitric oxide and lysozyme activity were significantly increased with dietary FOS. Study concluded with a remark that $2 \%$ dietary FOS was the most suitable and beneficial dose for Nile tilapia.

\section{Bacteria Pathogenicity in Tilapia Oreochromis niloticus}

Author Huicab-Pech ZG, et al. pedantically investigated the pathogenity against the Nile tilapia. Since this species is a choice of pisciculture or aquaculture in many diverse ecological systems as this species have tolerance to low water quality and disease. Author observed bacterial infections namely Aeromonas spp., Streptococcus spp., Edwardsiella spp. and Francisella spp., in the recent years, which accounts for $15 \%$ and $90 \%$ of mortality. Hence this article suggests measures for controlling the pathogenicity among Nile tilapia species to enhance the aqua production.

\section{Development in Food and Reproductive Biology of Tire-track Spiny Eel}

Tire-track Spiny Eel is also known as zig-zag eel and its scientific name is Mastacembelus armatus is a common fish of Indian subcontinent. Authors Gupta S and Banerjee S reviewed the nutritional value as well as the taste. The article gives consolidated information about the zig-zag eel species on its food, feeding habit and reproductive biology in turn supportive to the fishery and trade. 